\title{
A cytoskeleton-like role for the bacterial cell wall during engulfment of the Bacillus subtilis forespore
}

\author{
Angelica Abanes-De Mello, Ya-Lin Sun, Stefan Aung, and Kit Pogliano ${ }^{1}$ \\ Division of Biological Sciences, University of California, San Diego, La Jolla, California 92093-0349, USA
}

\begin{abstract}
A hallmark of bacterial endospore formation is engulfment, during which the membrane of one cell (the mother cell) migrates around the future spore, enclosing it in the mother cell cytoplasm. Bacteria lack proteins required for eukaryotic phagocytosis, and previously proteins required for membrane migration remained unidentified. Here we provide cell biological and genetic evidence that three membrane proteins synthesized in the mother cell are required for membrane migration as well as for earlier steps in engulfment. Biochemical studies demonstrate that one of these proteins, SpoIID, is a cell wall hydrolase, suggesting that membrane migration in bacteria can be driven by membrane-anchored cell wall hydrolases. We propose that the bacterial cell wall plays a role analogous to that of the actin and tubulin network of eukaryotic cells, providing a scaffold along which proteins can move.
\end{abstract}

[Keywords: Bacillus subtilis; sporulation; membrane movement; peptidoglycan hydrolysis; protein localization]

Supplemental material is available at http://www.genesdev.org.

Received September 9, 2002; revised version accepted October 21, 2002.

The movement and localization of macromolecules within the cell is a conserved and essential feature of both prokaryotic and eukaryotic organisms. In bacteria, such events are essential for chromosome segregation, cell division, and DNA replication, as well as for pathogenesis, chemotaxis, and the development of specialized cell types (Shapiro and Losick 1997; Jensen and Shapiro 2000). However, in contrast to eukaryotic cells, little is known about how macromolecules are moved or localized in bacterial cells. Indeed, the mechanism for the rapid separation of bacterial chromosomes remains unclear. Thus far, neither the distant bacterial homologs of actin (FtsA and MreB) nor that of tubulin (FtsZ) have been implicated in this process, and the only bacterial motor proteins identified so far (Smc/MukA) are instead required to separately condense the segregated chromosomes (Gordon and Wright 2000; Hiraga 2000; Lemon and Grossman 2001). Thus, the means by which bacteria move essential macromolecules such as DNA within their cell remains a mystery.

One dramatic example of the dynamic capabilities of bacterial cells is the phagocytosis-like process of engulfment (Fig. 1), a key step in the spore formation pathway of the endospore-forming bacteria, such as Bacillus sub-

${ }^{1}$ Corresponding author.

E-MAIL kpogliano@ucsd.edu; FAX (858) 822-1431.

Article and publication are at http://www.genesdev.org/cgi/doi/10.1101/ gad.1039902. tilis, B. anthracis, and various Clostridia species (for reviews, see Stragier and Losick 1996; Piggot and Losick 2002). Shortly after an asymmetrically positioned cell division event generates the smaller forespore and larger mother cell, the mother cell membrane migrates around the forespore, until the leading edges of the engulfing membrane meet and fuse, releasing the forespore into the mother cell cytoplasm, where spore assembly is completed. Engulfment thereby mediates a striking reorganization of the sporangium, from two cells that lie side by side, to an endospore in which one cell lies within the cytoplasm of another. Despite the fact that engulfment is essential for sporulation in all endosporeforming bacteria, it remains unclear how bacterial cells are able to mediate this phagocytosis-like process.

Genetic studies of sporulation resulted in the identification of several proteins involved in engulfment, SpoIIB (Margolis et al. 1993), SpoIID (Lopez-Diaz et al. 1986), SpoIIM (Smith et al. 1993), SpoIIP (Frandsen and Stragier 1995), SpoIIQ (Londoño-Vallejo et al. 1997), and SpoIIIE (Sharp and Pogliano 1999). It is now clear that mutants lacking either SpoIIB (Perez et al. 2000) or SpoIIQ (Sun et al. 2000) are able to complete engulfment, albeit more slowly than wild type. Furthermore, although SpoIIIE is required for the membrane fusion event that is the final step of engulfment, it is not required for membrane migration (Sharp and Pogliano 1999). Thus, the only known proteins essential for the early stages of engulfment are the mother cell-expressed proteins SpoIID, SpoIIM, and 
Figure 1. The sporulation pathway of $B$. subtilis. (A) Early in sporulation, a septum containing peptidoglycan (gray) separates the smaller forespore and larger mother cell. $(B)$ The first step of engulfment, septal thinning, commences as the peptidoglycan within the septum is thinned, a step requiring the mother-cell-expressed

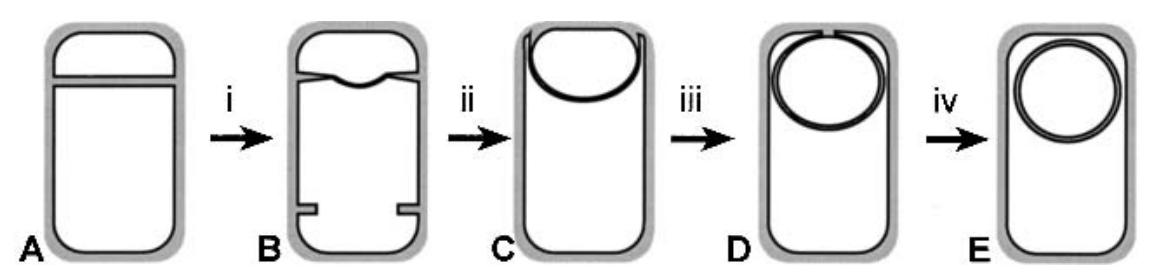
proteins SpoIID, SpoIIM, SpoIIP, and facilitated by SpoIIB. (C) Next, the mother cell membrane migrates up and around the forespore. Migration across the forespore pole requires the forespore-expressed SpoIIQ protein only under certain culture conditions (Sun et al. 2000). Ultimately, the migrating membrane meets $(D)$ and fuses $(E)$ at the forespore pole, a step requiring the SpoIIIE DNA translocase (Sharp and Pogliano 1999). Septal biogenesis allows activation of $\sigma^{\mathrm{F}}$ in the forespore and $\sigma^{\mathrm{E}}$ in the mother cell, and the completion of engulfment allows activation of $\sigma^{\mathrm{G}}$ in the forespore and $\sigma^{\mathrm{K}}$ in the mother cell.

SpoIIP, in keeping with the observation that mother cellspecific, but not forespore-specific, gene expression is required for engulfment (Sun et al. 2000). These three proteins are found in all endospore-forming bacteria whose genomes have been sequenced (Stragier 2002), suggesting that they play conserved and essential roles in sporulation. In addition, SpoIID is homologous to another $\mathrm{Ba}$ cillus protein, $\mathrm{LytB}$, which is thought to regulate the activity of the major vegetative cell wall hydrolase, LytC (Lopez-Diaz et al. 1986; Kuroda et al. 1992), an $\mathrm{N}$-acetylmuramoyl-L-alanine amidase involved in cell separation (Blackman et al. 1998).

SpoIID, SpoIIM, and SpoIIP are essential for the first step of engulfment, septal thinning, during which the peptidoglycan within the sporulation septum becomes thinner when viewed by electron microscopy, starting in the middle of the septum and proceeding toward the edges (Piggot et al. 1994; Piggot and Losick 2002). They are also required to mediate the dissolution of partial septa formed when division initiates at the second potential division site within the mother cell (Fig. 1B; Pogliano et al. 1999; Eichenberger et al. 2001). Both activities likely require localized peptidoglycan hydrolysis, although no biochemical studies of these proteins have been performed, and none of the identified B. subtilis hydrolases are essential for engulfment (Foster and Popham 2002). Although dispensable for engulfment, SpoIIB also participates in septal thinning as, in its absence, the septal peptidoglycan appears ragged, as though incomplete septal thinning has occurred throughout the septum (Perez et al. 2000). Despite this defect, the spoIIB mutant is able to slowly initiate and complete engulfment, with the engulfing membrane moving around the residual septal peptidoglycan. SpoIIB is therefore likely to be required for the complete dissolution of septal peptidoglycan, but not for membrane migration (Perez et al. 2000).

Thus far, despite the identification of mutants specifically defective in septal thinning or membrane fusion, and specific large-scale screens for engulfment-defective mutants, proteins essential for moving the engulfing membrane around the forespore remain unidentified. However, past studies of the essential mother cell-expressed engulfment proteins SpoIID, SpoIIM, and SpoIIP focused on the phenotypic analysis of null mutants, leaving open the possibility that these proteins are also re- quired for later steps in engulfment. Here we report the isolation of spoIID and spoIIP mutants defective in both septal thinning and membrane migration, supporting a role for SpoIID and SpoIIP throughout engulfment. We also demonstrate that SpoIID, SpoIIM, and SpoIIP initially localize to the septal midpoint, then spread throughout the septum prior to becoming enriched at the leading edge of the engulfing mother cell membrane, where they remain until the completion of engulfment. These results suggest that SpoIID, SpoIIM, and SpoIIP are involved in moving the engulfing membrane around the forespore, as well as in septal thinning. Finally, our biochemical studies indicate that one of these proteins, SpoIID, is a peptidoglycan hydrolase, suggesting that membrane migration in bacteria may be driven by the activity of membrane-anchored cell wall hydrolases that drag the membrane with them as they hydrolyze peptidoglycan.

\section{Results}

\section{A genetic screen for membrane migration-defective mutants}

We performed a large-scale genetic screen to identify mutants blocked at various stages of engulfment (Sharp and Pogliano 1999). The mutants isolated were visually screened for engulfment defects using the fluorescent membrane stain FM 4-64, which allows clear visualization of the sporulation septum at various stages of engulfment (Fig. 2A,C), and readily identifies mutants blocked at different stages of engulfment (Pogliano et al. 1999; Sharp and Pogliano 1999; Perez et al. 2000; Sun et al. 2000). For example, mutants defective in septal thinning show a characteristic "bulge" phenotype caused when the forespore pushes through the center of the unthinned septum and into the mother cell (arrows in Fig. $2 E, G)$. The forespores of such sporangia have a central constriction imposed by the septal peptidoglycan (see cartoon, Fig. 2I), and, in strains with null mutations in either spoIID, spoIIM, or spoIIP, membrane migration is completely blocked. In contrast, mutants slow to complete membrane migration, such as the spoIIQ mutant, show a smoothly curving septum (Sun et al. 2000; Fig. $2 \mathrm{Q}$, arrow). The failure of such mutants to complete en- 


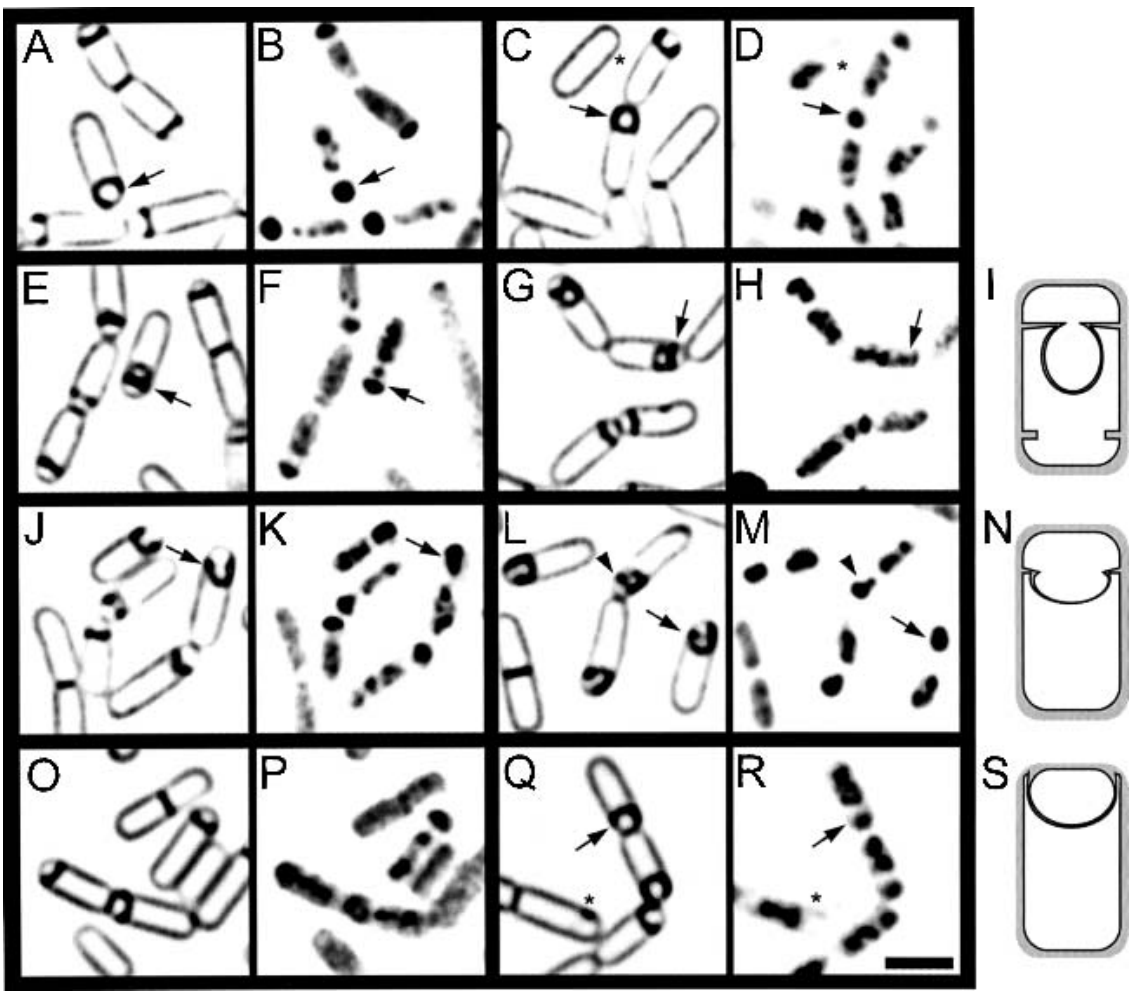

Figure 2. Engulfment phenotypes of spoIIP mutants. Sporangia were sampled 2 and $3 \mathrm{~h}$ after the onset of sporulation $\left(t_{2}\right.$, first and second columns; $t_{3}$, third and fourth columns, respectively), and the membranes stained with FM 4-64 (first and third columns) and the DNA stained with 6-diamidino-2-phenylindole (DAPI; second and fourth columns) and visualized with deconvolution microscopy. (A$D)$ Engulfment in the wild-type strain PY79. $(A, B)$ The sporulation septum is initially flat, and then the mother cell membrane begins to migrate around the forespore (arrows). (C,D) After the completion of membrane migration but prior to membrane fusion, the forespore membranes stain with FM 4-64, which is membrane impermeable (arrows), whereas after membrane fusion (asterisks), the forespore membranes and chromosomes fail to stain with FM 4-64 $(C)$ and DAPI $(D) .(E-H)$ Phenotype of a spoIIP null strain (KP719), showing the constricted bulge phenotype caused when the forespore breaks through the center of an unthinned septum into the mother cell (arrows). (I) Model of a constricted bulge, based on electron microscopy studies (Frandsen and Stragier 1995; Pogliano et al. 1999; Perez et al. 2000). The peptidoglycan (gray shading) remains within the sporulation septum, constricting the bulge. (J-M) Phenotype of the spoIIP95-2 strain (KP621). This mutant initiates but does not complete membrane migration, and many sporangia have a partial constriction remaining at the original position of the septum (arrows). (L) Constricted bulges (arrowhead) are also seen. $(N)$ Model of an open bulge, whose appearance suggests that the septal peptidoglycan no longer extends completely across the septum, and does not tightly constrict the forespore when a bulge forms. (O-R) Engulfment in the spoIIQ null strain (KP575), in which membrane migration is slow, but septal thinning is normal (Londoño-Vallejo et al. 1997), producing smoothly curving septa with no bulges (arrows). (S) Model of sporangium in which membrane migration but not septal thinning is defective. (R) Bar, $2 \mu \mathrm{m}$.

gulfment can be unambiguously assayed using fluorescence microscopy because the fluorescent membrane stain FM 4-64 is membrane impermeable and so fails to stain the forespore membranes when added to sporangia that have completed membrane fusion (Sharp and Pogliano 1999; Fig. 2C, asterisk).

This screen resulted in the isolation of membrane fusion-defective mutants, as previously reported (spoIIIE; Sharp and Pogliano 1999). We also isolated mutants that appeared to be defective in membrane migration. These mutants included one with a point mutation in spoIISA, a gene that is dispensable for engulfment and lacking from the genomes of most endospore-forming bacteria (Adler et al. 2001). We also isolated an allele of spoIIP (spoIIP95-2) with a phenotype distinct from that of the spoIIP null mutant in several respects. First, spoIIP95-2 sporangia have bulges that appear less constricted by septal peptidoglycan than those produced by spoIIP null sporangia (Fig. 2J, arrow). These "open bulges" suggest that the septal peptidoglycan no longer extends completely across the septum; indeed some spoIIP95-2 sporangia appear to have completed septal thinning because no constriction is noted. Second, the mother cell membrane was able to initiate but not complete membrane migration (Fig. 2L, arrow), in about $26 \%$ of all sporangia
(Table 1). We observed sporangia in which the mother cell membrane had moved as far as the forespore pole, but we failed to observe sporangia that had completed the membrane fusion event that is the final step of engulfment. The production of sporangia with open bulges distinguishes the spoIIP95-2 phenotype from that of a mutation conditionally defective in membrane migration but not in septal thinning (spoIIQ), which produces neither constricted nor open bulges (Fig. 2O,Q). These observations suggest that the spoIIP95-2 mutation decreases the rate of both septal thinning and membrane migration, and thus, that SpoIIP is required for both processes.

Sequencing of spoIIP95-2 identified a single mutation upstream of the spoIIP coding region, changing the consensus ribosome binding site from GGAGG to GGAGA. No additional mutations were identified within or downstream of the spoIIP coding region. Because the mutation changes the ribosome binding site away from the consensus sequence (Shine and Dalgarno 1974; Rocha et al. 1999; Ma et al. 2002), it is predicted to reduce spoIIP translation, suggesting that the mutant phenotype is a consequence of reduced levels of SpoIIP protein. Thus, the levels of SpoIIP appear to be crucial for the rate of both septal thinning and membrane migration. 
Table 1. Percent sporangia showing the indicated engulfment phenotype

\begin{tabular}{|c|c|c|c|c|c|c|c|c|c|c|c|}
\hline \multirow{2}{*}{$\begin{array}{l}\text { Engulfment } \\
\text { stage }^{\mathrm{a}}\end{array}$} & \multirow[b]{2}{*}{ Bulge $^{\mathrm{b}}$} & \multirow[b]{2}{*}{ Class $^{c}$} & \multicolumn{6}{|c|}{$37^{\circ} \mathrm{C}$} & \multicolumn{3}{|c|}{$44^{\circ} \mathrm{C}$} \\
\hline & & & $w t$ & $\Delta s p o I I P$ & spoIIP95-2 & $\Delta$ spoIID & spoIID38 & spoIID39 & $w t$ & $\Delta s p o I I D$ & spoIID39 \\
\hline \multirow[t]{3}{*}{ Early } & None & 1 & 12 & 14 & 15 & 38 & 21 & 23 & 5 & 37 & 28 \\
\hline & Closed & 2 & 1 & 32 & 27 & 41 & 3 & 25 & 0 & 24 & 34 \\
\hline & Open & 3 & 0 & 8 & 23 & 1 & 13 & 17 & 0 & 1 & 3 \\
\hline \multirow[t]{3}{*}{ Late } & None & 4 & 16 & 3 & 10 & 0 & 43 & 14 & 7 & 0 & 1 \\
\hline & Closed & 5 & 0 & 0 & 4 & 1 & 0 & 0 & 0 & 0 & 0 \\
\hline & Open & 6 & 0 & 1 & 12 & 0 & 8 & 3 & 0 & 1 & 1 \\
\hline Complete & None & 7 & 70 & 0 & 0 & 0 & 10 & 0 & 87 & 1 & 0 \\
\hline Others $^{\mathrm{d}}$ & & 8 & 1 & 43 & 10 & 20 & 2 & 18 & 0 & 37 & 34 \\
\hline
\end{tabular}

The engulfment phenotype was scored at $t_{3}$. Between 117 and 252 sporangia were scored for each strain.

${ }^{a}$ The stage of engulfment is defined as early if the septum is flat or slightly curved (Fig. 2A), late if the migrating membrane has reached the cell pole on at least one side (Fig. 2A, arrow), or complete if membrane fusion has occurred (Fig. 2C, asterisk).

${ }^{b}$ Bulges are defined as closed if they appear either fully constricted by septal peptidoglycan, such that the flat portion of the septum completely traverses the mother cell (i.e., Fig. 2E, arrow), or if they appear mostly constricted by septal peptidoglycan, such that the constriction leaves a central opening that is less than half the width of the mother cell. Bulges are defined as open if they show an obvious constriction with a central opening at least half the width of the mother cell (i.e., Fig. 2J, arrow).

'Examples from each class are labeled with arrows as follows: Class 1-Figure 3A; Class 2-Figure 2E; Class 3-Figure 3M; Class 4-Figure 2A; Class 6-Figure 2L; Class 7-Figure 2C.

${ }^{\mathrm{d}}$ Includes collapsed forespores (Pogliano et al. 1999) and lysed sporangia (Supplemental Fig. 1S).

\section{Localized mutagenesis of spoIID}

We also performed localized mutagenesis of spoIID in an attempt to isolate mutations that block engulfment after septal thinning. A plasmid encoding spoIID was mutagenized by polymerase chain reaction $(\mathrm{PCR})$, and introduced into a spoIID null strain of $B$. subtilis, where it integrated into the nonessential amyE locus by homologous recombination. Alleles that failed to fully complement the spoIID null mutation were isolated and characterized further. We isolated two mutants that were able to proceed past the stage of septal thinning and initiate membrane migration, but which were unable to complete membrane fusion. One of these mutations, spoIID39, is strongly temperature sensitive (Ts) for engulfment: engulfment and spore formation occurs at nearly wild-type levels at the permissive temperature, whereas at the nonpermissive temperature, the mutant appears similar to the spoIID null mutant in terms of both spore production (Table 2) and engulfment phenotype, producing constricted bulges and failing to initiate membrane migration (Supplementary Fig. 1; Table 1). However, at the semipermissive temperature, the mutant produces an intermediate level of spores, and fluorescence microscopy demonstrated that it produces both open bulges (Fig. 3M, arrow) and closed bulges (Fig. 3O, arrowhead), and initiates but fails to complete membrane migration (Fig. 3O, arrow). This suggests that under conditions in which SpoIID39 protein is partially active, the rate of both septal thinning and membrane migration are reduced.

The second spoIID mutation, spoIID38, reduced spore formation by twofold at all temperatures. The spoIID38 sporangia showed an engulfment defect similar to that of spoIIP95-2 and spoIID39 at $37^{\circ} \mathrm{C}$, producing sporangia with slowed membrane migration (arrows in Fig. 3I,K). The spoIID38 sporangia were able to slowly complete engulfment, as by $t_{3}, 10 \%$ of sporangia completed membrane fusion (Fig. 3K, asterisk), compared with $70 \%$ of wild-type sporangia (Table 1). DNA sequence analysis revealed that the spoIID38 gene had three mutations, one of which changed an amino acid in the N-terminal hydrophobic segment of SpoIID from leucine to proline (L8 to $\mathrm{P}$ ), another of which was upstream of the coding region (at nucleotide -50 from the ATG, C to T), and the third of which was a silent mutation changing an arginine codon from AGA to AGG (R111 to R). It seems probable that the L8-to-P mutation causes the mutant phenotype. Although this leucine is not conserved in any SpoIID homolog, the introduction of proline into the hy-

Table 2. Spore production by various Bacillus subtilis strains

\begin{tabular}{llccc}
\hline & & \multicolumn{3}{c}{$\begin{array}{c}\text { Number of heat-resistant spores/ } \\
\text { mL of culture }\end{array}$} \\
\cline { 3 - 5 } Strain & \multicolumn{1}{c}{ Allele } & $30^{\circ} \mathrm{C}$ & $37^{\circ} \mathrm{C}$ & $44^{\circ} \mathrm{C}$ \\
\hline PY79 & wt & $6.5 \times 10^{8}$ & $6.8 \times 10^{8}$ & $5.0 \times 10^{8}$ \\
KP7 & spoIID298 & $5.2 \times 10^{2}$ & $3.5 \times 10^{2}$ & $8.7 \times 10^{1}$ \\
KP519 & spoIIM::Tn917 & N.D. & $1.2 \times 10^{2}$ & N.D. \\
KP719 & spoIIP::tet & N.D. & $4.0 \times 10^{1}$ & N.D. \\
KP718 & wt & $3.3 \times 10^{8}$ & $4.8 \times 10^{8}$ & $3.7 \times 10^{8}$ \\
KP38 & spoIID38 & $1.1 \times 10^{8}$ & $2.1 \times 10^{8}$ & $1.0 \times 10^{8}$ \\
KP39 & spoIID39 & $3.8 \times 10^{7}$ & $2.1 \times 10^{6}$ & $9.7 \times 10^{2}$ \\
KP555 & wt & N.D. & $2.6 \times 10^{8}$ & N.D. \\
KP621 & spoIIP95-2 & N.D. & $5.2 \times 10^{6}$ & N.D. \\
KP720 & gfp-spoIID & N.D. & $4.1 \times 10^{8}$ & N.D. \\
KP721 & gfp-spoIIM & N.D. & $6.7 \times 10^{8}$ & N.D. \\
KP722 & gfp-spoIIP & N.D. & $7.1 \times 10^{8}$ & N.D. \\
\hline
\end{tabular}

Spore titer was determined $48 \mathrm{~h}, 24 \mathrm{~h}$, or $18 \mathrm{~h}$ after the initiation of sporulation in Difco Sporulation Medium at $30^{\circ} \mathrm{C}, 37^{\circ} \mathrm{C}$, and $44^{\circ} \mathrm{C}$, respectively.

(wt) Wild type; (N.D.) not determined. 


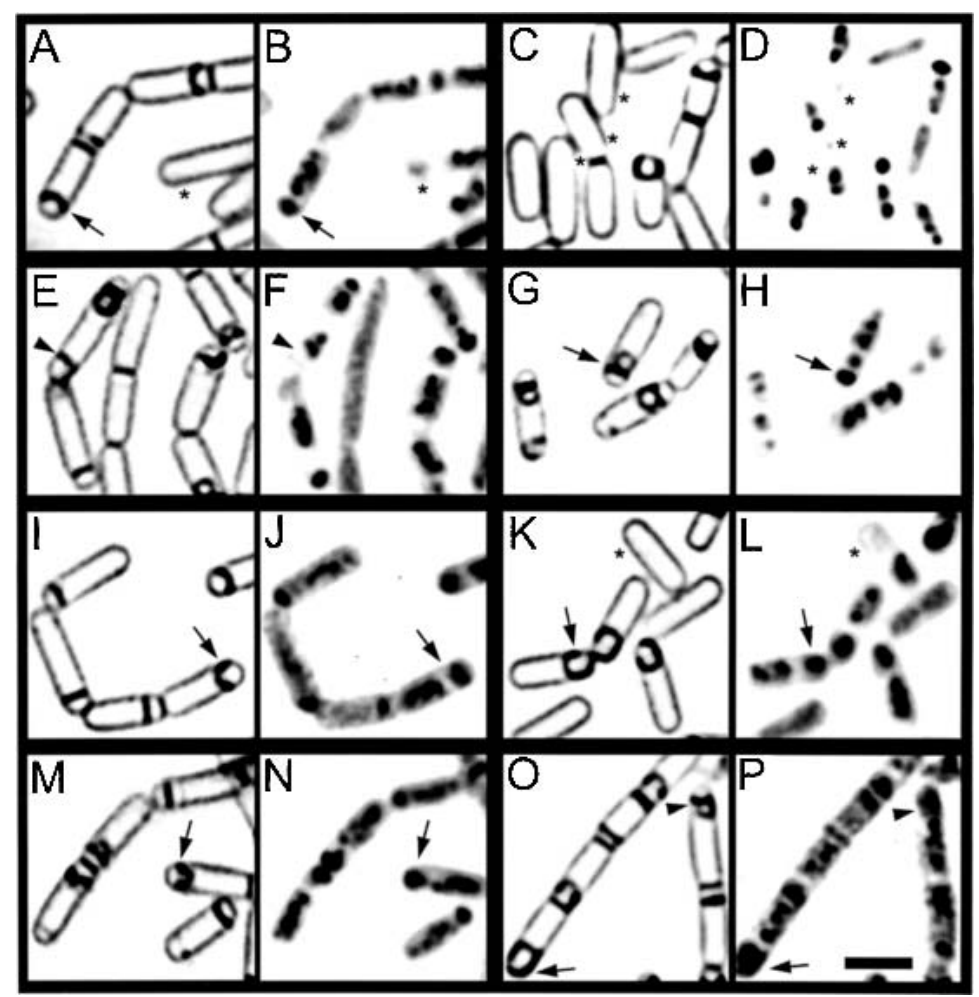

Figure 3. Engulfment phenotypes of spoIID mutants. Samples from $t_{2}$ (first and second columns) and $t_{3}$ (third and fourth columns) were stained with FM 4-64 (first and third columns) and 6-diamidino-2-phenylindole (second and fourth columns). (A-D) Wild type (PY79), showing smoothly curving septa characteristic of engulfment in wild type (arrows). (C,D) After membrane fusion, the forespore membranes and DNA fail to stain (asterisks). (E-H) A spoIID null strain (KP7), showing constricted bulges (arrows), and a second septum that is retained in the mother cell in septal thinning defective mutants (arrowheads). (I-L) Phenotype of the spoIID38 strain (KP38), showing sporangia that have initiated engulfment but appear similar to wild type (arrows). Membrane migration is slow, and sporangia that have not completed migration accumulate later in sporulation $(K, L)$; very few sporangia complete membrane fusion (asterisk; Table 1). $(M-P)$ Phenotype of the spoIID39 Ts strain at the semipermissive temperature $\left(37^{\circ} \mathrm{C}\right)$. This mutant produces open bulges $(M$, arrow $)$ and closed bulges $(O$, arrowhead $)$ and initiates but fails to complete membrane migration $(O$, arrow $) .(P)$ Bar, $2 \mu \mathrm{m}$. drophobic core of a membrane-spanning segment or signal sequence is expected to dramatically affect its structure, perhaps inhibiting insertion into the membrane bilayer. The spoIID39 gene had two mutations, one changed a conserved threonine to an aspartate (T107D), and the other changed a nonconserved glutamate to glycine (E247G).

\section{Localization of the mother cell-expressed engulfment proteins}

If SpoIID, SpoIIM, and SpoIIP are involved in both membrane migration and septal thinning, then the proteins would be expected to localize to the septum and to the leading edge of the engulfment membrane. To test this prediction, we fused green fluorescent protein of Aequorea victoria (GFP) to the cytoplasmic $\mathrm{N}$ terminus of SpoIID, SpoIIM, and SpoIIP, because the C terminus of each is predicted to be extracellular and GFP is not fluorescent when exported from bacterial cells via the general secretory pathway (Feilmeier et al. 2000). The spoIID promoter was used to express the fusion genes, and each fully complemented the respective null mutations, producing wild-type levels of spores (Table 2).

We found that both GFP-SpoIIP and GFP-SpoIIM localized to the sporulation septum (Fig. 4A, arrow 1, B, arrow 4), and to the second division site within the mother cell (Fig. 4B, arrowhead), consistent with a role for these proteins in septal thinning and repressing division within the mother cell. Interestingly, both GFPSpoIIP (data not shown) and GFP-SpoIIM (Fig. 4B, arrow
3) initially localized to the septal midpoint, where septal thinning likely starts. Importantly, both GFP-SpoIIP and GFP-SpoIIM were most concentrated at the leading edge of the engulfing membrane (Fig. 4A, arrow 2, B, arrow 4), where they remained throughout membrane migration. This is in contrast to a protein required only for septal thinning (SpoIIB), which initially localizes to the septum, but delocalizes by the start of membrane migration (Perez et al. 2000). GFP-SpoIIM also localized to the forespore distal pole in later sporangia in which engulfment was more complete (Fig. 4B). This localization pattern might be caused by overexpression of GFP-SpoIIM from the spoIID promoter, which is about fourfold more active than the spoIIM promoter (A. Rubio, pers. comm.). Thus, the localization of SpoIIM and SpoIIP suggests that both proteins are required for membrane migration as well as for septal thinning.

GFP-SpoIID also localized to the sporulation septum (Fig. 4C, arrow 5), although a significant amount of GFP fluorescence was also observed throughout the mother cell cytoplasmic membrane. This diffuse fluorescence may be due to the presence of a potential leader peptidase recognition sequence within SpoIID, which if cleaved would release GFP fused to a signal sequence, which would likely freely diffuse within the mother cell membrane. In addition to this diffuse fluorescence, sporangia that had commenced membrane migration showed a high concentration of GFP-SpoIID at the leading edge of the engulfing membrane, similar to SpoIIP and SpoIIM (Fig. 4C, arrow 6). Thus, similar to SpoIIP and SpoIIM, SpoIID localizes to the septum and to the 
Figure 4. Localization of the essential engulfment proteins. Localization of GFPSpoIIP ( $A$, green), GFP-SpoIIM ( $B$, green), and GFP-SpoIID ( $C$, green), in sporangia sampled $1 \mathrm{~h}$ and $45 \mathrm{~min}$ after the initiation of sporulation by resuspension. The membranes are stained with Mitotracker Red (red, see Materials and Methods). (A) GFP-SpoIIP (strain KP722), showing the protein lining the septum in sporangia that have not initiated membrane migration (arrow 1), and forming foci at the leading edge of the engulfing membrane (arrow 2). (B) GFP-SpoIIM (strain KP721), showing localization as a focus at the septal midpoint in very early sporangia (arrow 31 , and forming foci at the edges of the sporulation septum (arrow 4). The protein also localizes to the division site within the mother cell (arrowhead) and to the forespore distal pole of the mother cell. (C) GFP-SpoIID (strain KP720), showing sporangia in which SpoIID localizes to the sporulation septum (arrow 5) and forms foci at the leading edge of the engulfing membrane (arrow 6). A significant amount of GFP fluorescence is also observed in the mother cell cytoplasmic membrane. Bar, $2 \mu \mathrm{m}$. (D) Model showing the localization of the essential engulfment proteins (green circles), each of which initially localizes in the middle of the sporulation septum, then moves across the septum and forms foci at the leading edge of the engulfing membrane.
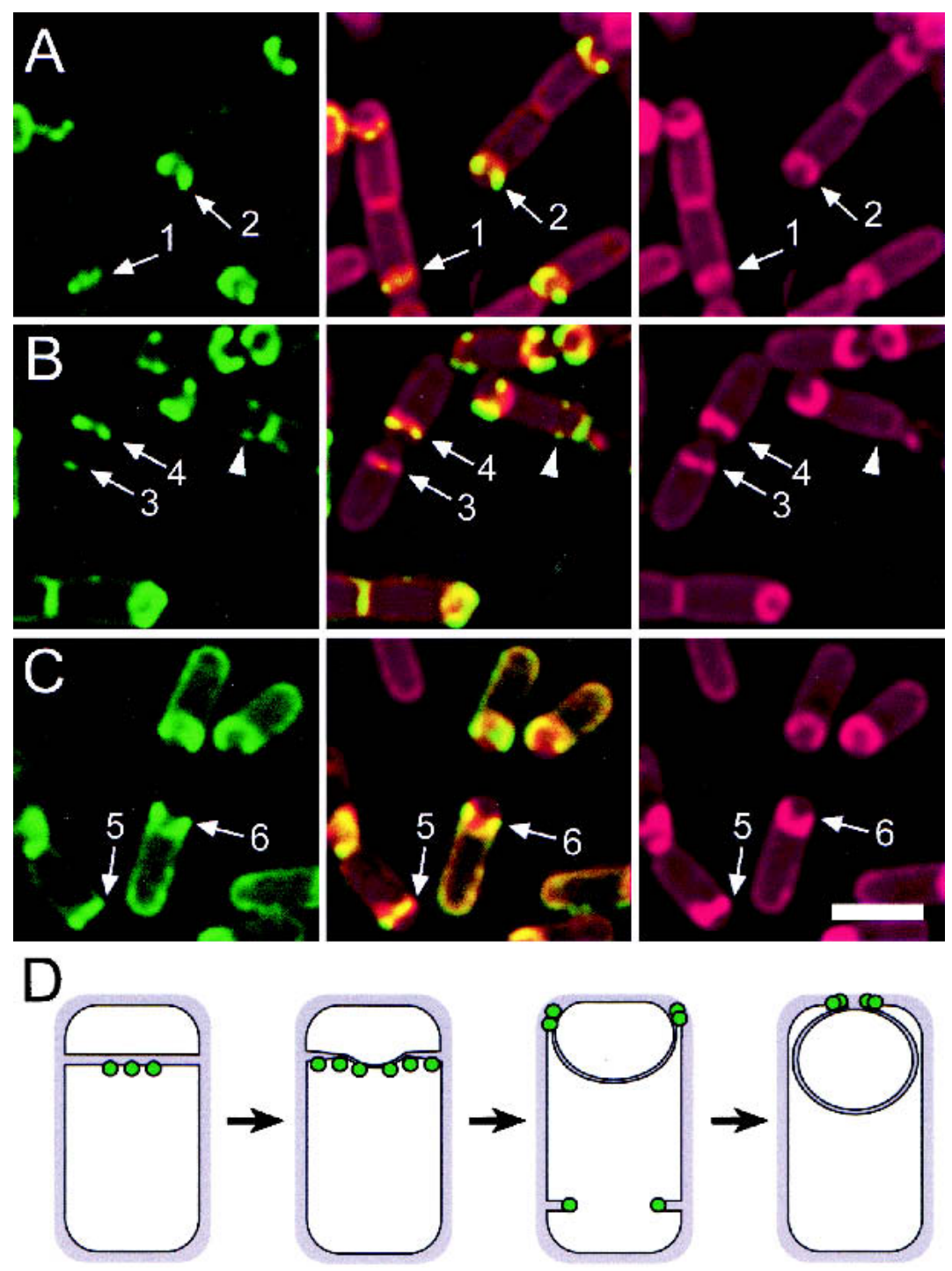

leading edge of the engulfing membrane, consistent with our genetic data implicating SpoIID in membrane migration as well as septal thinning.

\section{SpoIID is a peptidoglycan hydrolase}

The previously described roles of SpoIID, SpoIIM, and SpoIIP in the thinning of septal peptidoglycan and in the retraction of partial septa within the mother cell suggested that they might be involved in peptidoglycan degradation (Pogliano et al. 1999). However, although all of these proteins are conserved in all endospore-forming bacteria, none are homologous to enzymes known to hydrolyze peptidoglycan [although SpoIID is homologous to a protein that regulates the activity of one such protein (Lopez-Diaz et al. 1986; Kuroda et al. 1992)]. We were therefore interested in determining if any of these proteins were able to degrade bacterial cell walls. For these biochemical studies, we focused on SpoIID and SpoIIP because each has a large extracellular domain, as do many known peptidoglycan hydrolases (Foster and Popham 2002), whereas SpoIIM is an integral membrane protein and lacks a substantial extracellular domain.

We overexpressed His-tagged SpoIID and SpoIIP in Escherichia coli, purified the proteins, and used renaturing polyacrylamide gel electrophoresis to test their ability to hydrolyze bacterial cell walls incorporated into a polyacrylamide gel (Foster 1992). This assay showed that SpoIID was able to degrade both Micrococcus luteus (Fig. 5B) and B. subtilis cell walls (Fig. 5C), clearing peptidoglycan from the gel at the position of full-length SpoIID and of a larger copurifying protein that might be a SpoIID multimer. Remarkably, less SpoIID than lysozyme was required to solubilize the peptidoglycan to the same extent. SpoIIP did not consistently demonstrate hydrolase activity in these gels (data not shown). Further tests of biochemical activities for SpoIIP, and the more precise description of the precise hydrolytic activity of SpoIID, will require the purification of both proteins in an active and soluble state. However, our biochemical studies to 

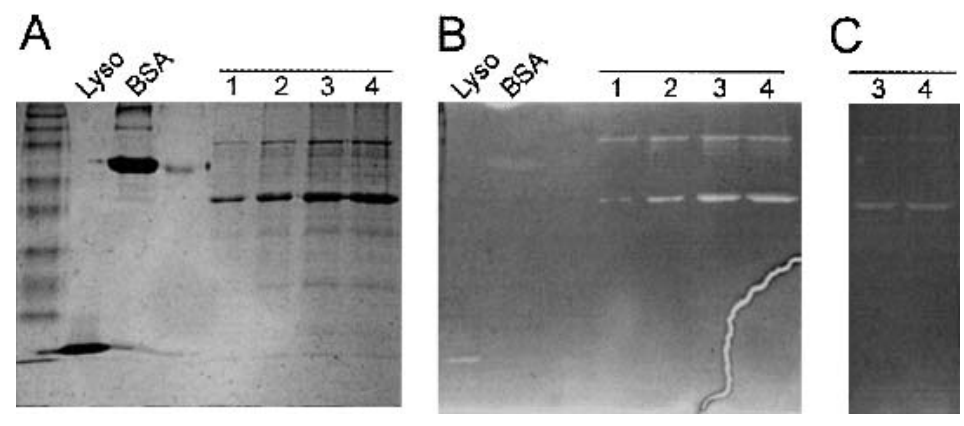

Figure 5. SpoIID shows peptidoglycan hydrolase activity. Various amounts of purified SpoIID was loaded on the gel, together with lysozyme (Lyso) as a positive control and bovine serum albumin (BSA) as a negative control. (A) Coomassie-stained SDS-polyacrylamide gel showing the identical amount of proteins loaded as in panels $B$ and $C .(B, C)$ Renaturing SDS-polyacrylamide gels containing $M$. luteus $(B)$ cells or purified $B$. subtilis (C) walls as a substrate (see Materials and Methods). After electrophoresis, the gels were incubated overnight in renaturation solution and the remaining peptidoglycan was stained with methylene blue, showing bands of clearing at the position of lysozyme (Lyso) and SpoIID. date demonstrate that SpoIID is a highly active peptidoglycan hydrolase capable of solubilizing both $B$. subtilis and M. luteus peptidoglycan.

The leading edge of the engulfing membrane advances adjacent to the cell wall

If movement of the mother cell membrane around the forespore is mediated by the peptidoglycan hydrolase activity of SpoIID, then one would expect that the engulfing membrane would advance most rapidly adjacent to the cell wall. We therefore used ultrathin section transmission electron microscopy to provide a high-resolution image of the leading edge of the engulfing membrane. We consistently observed that during membrane migration, the leading edge of the mother cell membrane is in close contact with the cell wall (Fig. 6, arrow), whereas the lagging portion of the engulfing membrane is away from the cell wall (see also Fig. 4 in Perez et al. 2000). Thus, electron microscopic analysis suggests that the leading edge of the engulfing membrane moves around the forespore immediately adjacent to the cell wall.

\section{Discussion}

Here we provide genetic and cell biological evidence that three mother cell-expressed proteins are required for the movement of the mother cell membrane around the forespore during the phagocytosis-like process of engulfment. First, we isolated mutations predicted to reduce the level of active SpoIID and SpoIIP protein, and found that these mutations reduce both the rate of septal thinning and membrane migration. Second, we localized SpoIID, SpoIIM, and SpoIIP, and found that each is enriched at the leading edge of the engulfing membrane, where they remain until the completion of membrane migration. Together, this cell biological and genetic evidence strongly suggests that these three proteins are involved in the movement of the mother cell membrane around the forespore, as well as in thinning of the septal peptidoglycan. SpoIID, SpoIIM, and SpoIIP are likely to be the only essential engulfment proteins that are dispensable for growth, because the genetic screen reported here, and a similar screen in another laboratory, failed to identify any new engulfment proteins (P. Eichenberger and R. Losick, pers. comm.). Furthermore, we previously demonstrated that only mother cell-specific gene expression is essential for engulfment (Sun et al. 2000), and Eichenberger and Losick have inactivated all $\sigma^{\mathrm{E}}$-transcribed genes identified by microarray analysis, yet failed to identify any new engulfment proteins (P. Eichenberger and R. Losick, pers. comm.). Although it remains possible that other sporulation-specific proteins play subtle or redundant roles in engulfment, and that proteins essential for viability play a crucial role in engulfment, it

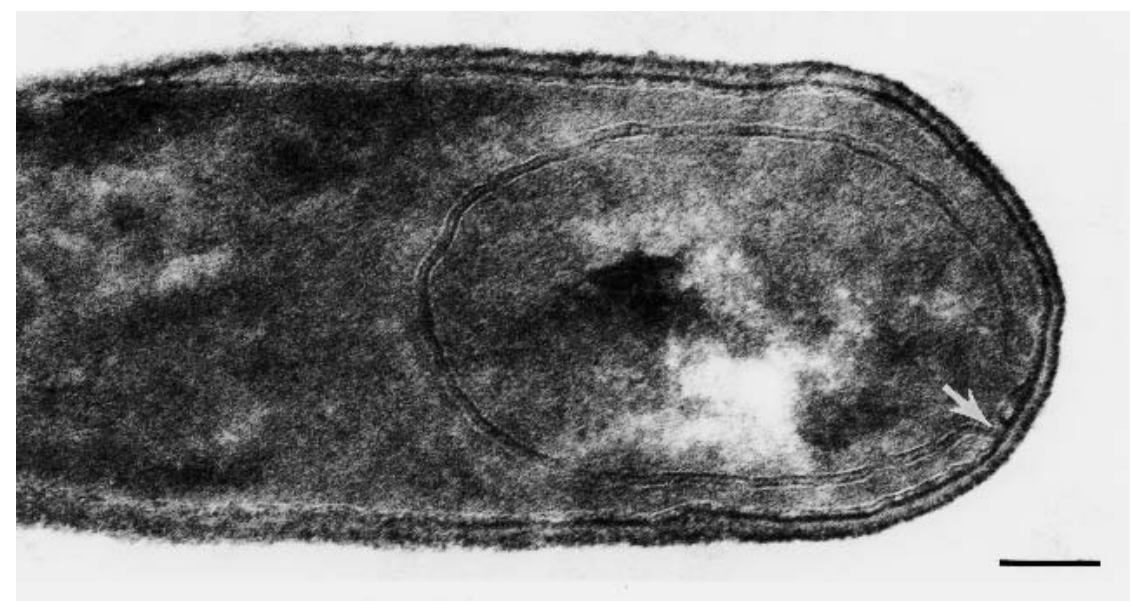

Figure 6. Transmission electron micrograph of wild-type B. subtilis (PY79) at a late stage of engulfment. Samples were taken at $2 \mathrm{~h}$ after onset of sporulation and prepared for thin section electron microscopy (Materials and Methods). The arrow points to the leading edge of the engulfing membrane, showing that the membrane maintains close contact with the cell wall, and that the remaining portion of the engulfing membrane lags behind this advancing edge. Figure 7 is a cartoon of the leading edge structure indicated by the arrow, rotated so that the cell wall is on the top, and engulfment proceeds to the right. Bar, $100 \mathrm{~nm}$. 
seems likely that, of the sporulation-specific proteins, SpoIID, SpoIIM, and SpoIIP comprise the essential engulfment machinery.

We have demonstrated that one of these proteins, SpoIID, is a peptidoglycan hydrolase capable of solubilizing both $B$. subtilis and $M$. luteus cell peptidoglycan in a renaturing gel electrophoresis assay. This enzymatic activity is consistent with the requirement for SpoIID in septal thinning and is the first direct demonstration that septal thinning requires peptidoglycan hydrolysis. The observation that reducing the level of SpoIID activity also slows membrane migration suggests that peptidoglycan hydrolase activity is required for membrane migration. SpoIID is the founding member of a new class of peptidoglycan hydrolases that includes SpoIID homologs of other endospore-forming bacteria, proteins of unknown function in cyanobacterial genomes, and B. subtilis LytB (Kuroda et al. 1992), which has been previously reported to regulate the activity of a major peptidoglycan hydrolase (LytC). Our results demonstrate that at least certain members of this family of proteins are peptidoglycan hydrolases capable of mediating dynamic events in bacterial cells.

We can imagine two distinct mechanisms by which peptidoglycan hydrolase activity might contribute to membrane migration during engulfment. First, it is possible that peptidoglycan hydrolysis is necessary to remove bridges between the forespore membrane and the cell wall, such as those that might be formed by lipoteichoic acid. Such bonds might impede movement of the mother cell membrane around the forespore. If so, then membrane migration might be expected to occur more slowly immediately adjacent to the cell wall. In contrast, our electron micrographs show that engulfment proceeds most rapidly adjacent to the cell wall, with the cell wall distal portion of the leading edge lagging behind that adjacent to the cell wall. In addition, a previous study suggested that the cell wall was necessary for engulfment because sporulation was blocked if the wall was removed by enzymatic digestion in osmotically buffered medium before, but not after, engulfment (FitzJames 1964). The second model proposes that peptidoglycan hydrolysis plays a more active role in engulfment because a membrane-anchored protein complex that includes a peptidoglycan hydrolase could drag the mother cell membrane along as it hydrolyzes peptidoglycan surrounding the forespore (Fig. 7). In this model, the energy for membrane movement could be provided by the hydrolysis of a large number of bonds in the peptidoglycan, which might be sufficient to power this relatively slow process (which requires $\sim 45 \mathrm{~min}$ to complete). This model suggests that the bacterial cell wall provides an external scaffold along which motor proteins can move, similar to the eukaryotic cytoskeleton.

Previous observations support an analogy between the bacterial cell wall and the eukaryotic cytoskeleton. First, like the eukaryotic cytoskeleton, the bacterial cell wall plays a crucial role in determining and maintaining cell shape (Holtje 1998). Second, both the peptidoglycan biosynthesis machinery and several cell wall hydrolases are

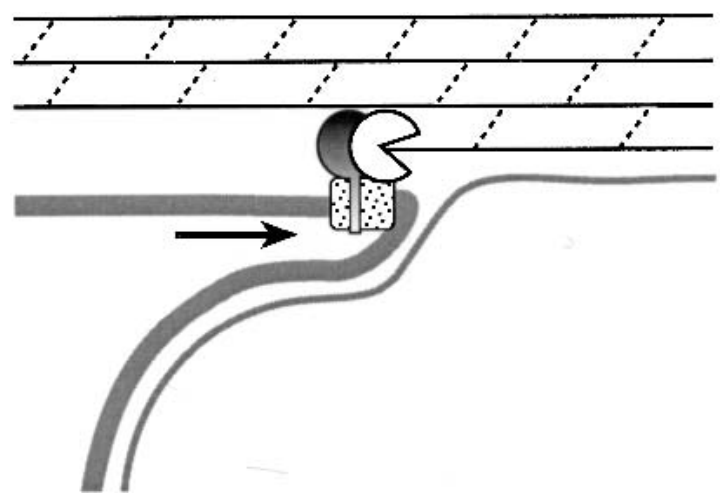

Figure 7. Model for peptidoglycan hydrolysis-driven membrane migration. A schematic depiction of the leading edge of the engulfing mother cell membrane (thick gray line) as it moves around the forespore (in the direction indicated by the arrow). Note that the engulfing membrane moves between the forespore membrane (thin gray line) and the peptidoglycan, which consists of glycan chains (solid black lines) linked by peptide cross-bridges (broken black lines). We propose that movement of the membrane around the forespore is mediated by a membrane-anchored protein complex including SpoIID (pacman), SpoIIP (shaded lollipop), and SpoIIM (speckled box), which hydrolyzes the peptidoglycan adjacent to the forespore membrane, thereby moving the mother cell membrane around the forespore. In this model, the inherent chemical polarity of peptidoglycan could determine the direction that proteins move along the cell wall, just as the polarity of actin and tubulin filaments determines the direction that motor proteins move along the eukaryotic cytoskeleton.

processive enzymes that likely move along the peptidoglycan strands as they synthesize or degrade cell wall polymers (Barrett et al. 1984; Holtje 1996, 1998). Interestingly, biochemical studies of the SpoIID homolog LytB have suggested that it confers processivity on the enzyme with which it interacts (Herbold and Glaser 1975). We therefore predict that the SpoIID peptidoglycan hydrolase for a protein complex that includes SpoIID) is a processive enzyme that translocates along the glycan chains, thereby moving the mother cell membrane around the forespore.

\section{Materials and methods}

Bacterial strains, genetic manipulations, and growth conditions

B. subtilis strains (Table 3) used in this study are derivatives of wild-type strain PY79 (Youngman et al. 1984). Mutations and the various plasmid constructs were introduced into PY79 by transformation (Dubnau and Davidoff-Abelson 1971). B. subtilis was grown and sporulated at $37^{\circ} \mathrm{C}$ unless otherwise specified. Sporulation was induced by the resuspension method (Sterlini and Mandelstam 1969) or by nutrient exhaustion in Difco Sporulation Medium (DSM; Schaeffer et al. 1965). Sporulation efficiency was determined after heating cultures at $80^{\circ} \mathrm{C}$ for 20 min at $48 \mathrm{~h}$ after induction of sporulation for $30^{\circ} \mathrm{C}$ cultures, 24 $\mathrm{h}$ for $37^{\circ} \mathrm{C}$ cultures, and $18 \mathrm{~h}$ for $44^{\circ} \mathrm{C}$ cultures. Standard PCR conditions (Qiagen Taq Polymerase Kit and Roche Expand Hi- 
Table 3. Bacterial strains used in this study

\begin{tabular}{|c|c|c|}
\hline Strain & Genotype & Reference \\
\hline \multicolumn{3}{|c|}{ Bacillus subtilis } \\
\hline PY79 & Wild type & Youngman et al. 1984 \\
\hline KP7 & spoIID298 & Lopez-Diaz et al. 1986 \\
\hline KP38 & 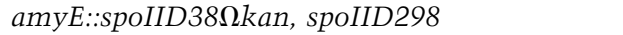 & This study \\
\hline KP39 & 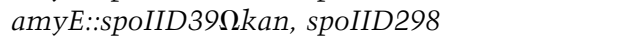 & This study \\
\hline KP519 & spoIIM::Tn917 & Sandman et al. 1987 \\
\hline KP555 & thr::cotD-lacZ $\Omega m l s, \cot E-g f p \Omega k a n$ & Sharp and Pogliano 1999 \\
\hline KP621 & spoIIP95-2, thr::cotD-1acZ $\Omega m l s, \cot E-g f p \Omega k a n$ & This study \\
\hline KP718 & amyE::spoIID $\Omega$ kan, spoIID298 & This study \\
\hline KP719 & spoIIP::tet & Frandsen and Stragier 1995 \\
\hline KP720 & amyE::gfp-spoIID $\Omega$ cat, spoIID298 & This study \\
\hline KP721 & 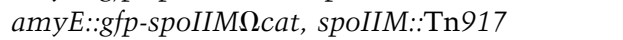 & This study \\
\hline KP722 & 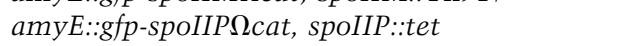 & This study \\
\hline \multicolumn{3}{|c|}{ Escherichia coli } \\
\hline KJ622 & Strain TG1, pcnB uvc24-1 & This study \\
\hline
\end{tabular}

Fidelity PCR System) were used. Two E. coli strains were used to propagate the various plasmids used in this study, DH5 $\alpha$ and KJ622 (TG1, pcnB uvc24-1). Sequencing of plasmid constructs or of PCR-amplified chromosomal DNA was conducted by the Shared Resource UCSD Cancer Center.

\section{Localized mutagenesis of spoIID}

An $a m y E$ integrational vector encoding wild-type spoIID was constructed by cloning a 2-kb EcoRI-to-BamHI fragment including the spoIID gene from p16-2 (a gift of A. Decatur and R. Losick) into EcoRI- and BamHI-digested pER82 (Driks et al. 1994). The resulting plasmid (pKP1) was PCR mutagenized with Taq DNA polymerase (Zhou et al. 1991), using the primers KJPO3 (5'-CTCCAGTCTTCACATC-3') and KJPO6 (5'-GCCC TCCCGTATCGTAG-3') to amplify an $8.1-\mathrm{kb}$ fragment comprising most of the plasmid backbone and the $a m y E$ DNA that flanks both spoIID and the B. subtilis selectable marker kan. The PCR fragments were directly transformed into freshly prepared competent cells of the B. subtilis spoIID null mutant strain KP7. Transformants were selected by plating on DSM plates containing $3 \mu \mathrm{g} / \mathrm{mL}$ kanamycin, and incubated at either room temperature, $30^{\circ} \mathrm{C}, 37^{\circ} \mathrm{C}$, or $44^{\circ} \mathrm{C}$. The PCR mutagenesis was highly effective, as between $6 \%$ and $50 \%$ of all transformants failed to complement the spoIID null mutation. Transformants that were either partially or completely sporulationdefective were colony purified and tested for temperature- or cold-sensitive sporulation defects, and for mutations that only partially complemented the spoIID mutation. The mutations in two such strains, KP38 and KP39 were sequenced following PCR amplification of the spoIID coding region using primers AADO31 (5'-GAGGGATTTTTGACTCCGAAG-3') and AADO32 (5'-CAAACGCCTTTCCGTGG-3'), which hybridize to the amyE flanking DNA. In the course of these studies, we sequenced the spoIID298 mutation of KP7, and found that it changed codon 145 (normally encoding Gln) to an amber codon (CAG to TAG).

\section{Isolation of spoIIP95-2}

Possible peptidoglycan thinning or membrane migration mutants from a screen described previously (Sharp and Pogliano 1999) were introduced into a nonmutagenized background (strain KP555) by transformation as described (Sharp and Pogliano 1999), and microscopically screened to ensure that the origi- nal engulfment phenotype had been retained. To identify the mutant gene, we transformed into these strains a plasmid library consisting of $B$. subtilis genomic fragments cloned into the amyE integration vector pDG1730 (Guerout-Fleury et al. 1996), in which the cat gene was replaced with a spec gene. Transformants were screened for $\mathrm{Spo}^{+}$colonies on DSM plates containing $80 \mu \mathrm{g} / \mathrm{mL}$ X-gal and $5 \mu \mathrm{g} / \mathrm{mL}$ chloramphenicol. Such transformants contained a DNA fragment that either complemented or marker rescued the original spo mutation. The cloned chromosomal DNA was identified by using ligation-mediated PCR using the Universal Genome Walker Kit (Clontech). In brief, chromosomal DNA was prepared and digested with either DraI or RsaI, and ligated to the GenomeWalker Adapters. Two specific primers were used in the PCR amplification, one hybridized to the $a m y E$ region of the plasmid (KXGSP1 5'-TGC CAGTCACGTTACGTTATTAGTTATAGT-3'), the other upstream of the cat gene KXGSP2 $\left(5^{\prime}\right.$-TATAACATGTATTCAC GAACGAAAATCGC-3'), and two primers to the GenomeWalker Adapter (AP1, 5'-GTAATACGACTCACTATAGGGC$3^{\prime}$ and AP2 5'-ACTATAGGGCACGCGTGGT-3') were used to amplify the cloned $B$. subtilis DNA. The PCR product was sequenced using the second internal primer (KXGSP2) to identify the cloned genomic DNA.

\section{Construction of GFP fusions}

N-terminal GFP fusions to SpoIID, SpoIIM, and SpoIIP were constructed by PCR amplification of the respective wild-type genes from PY79 chromosomal DNA, using the following primers: spoIID (AADO3 5'-CTCGGCCGCAATTCGCAATCAC ACTATCCG-3' and AADO4 5'-CTCGGCCGCAGGAACAA GAAAAAGACGC-3', EagI site underlined), spoIIM (AADO5 5'-GACGGCCGCGAAAAATCTCTTATAAGGACATGTTT CTCAGGC-3' and AADO6 5'-CTCGGCCGCGCCGCATTC CATGACTC-3', EagI site underlined), and spoIIP (AADO7 5'GAAGGGGCCCAGAAATAAACGCAGAAACAGACAGATT GTTGTTGCGG-3' and AADO 8 5'-GGAAGGGCCCGCCGAAC AGAACGCCTAAAAACATGATCGTGAC-3', PspOMI site underlined). Fragments were digested by the appropriate restriction enzymes and ligated into EagI-digested pMDS14, in which the spoIID promoter and translational initiation signals are fused to GFP (Sharp and Pogliano 2002). A pcnB derivative of TG1 (strain $\mathrm{KJ} 622$ ) was used as the E. coli cloning strain for these studies. The pcnB mutation reduces plasmid copy number (Lopilato et al. 1986) and alleviates the toxicity of spoIIM and spoIIP to E. coli strains. 
The resulting plasmids were sequenced, and then transformed into the respective null mutant strains. Each fully complemented the null mutation and supported wild-type levels of spore production.

\section{Microscopy and image analysis}

To assess the completion of engulfment, we harvested samples of sporulating bacteria at the appropriate time, and stained them with a final concentration of $5 \mu \mathrm{g} / \mathrm{mL}$ FM 4-64, $0.2 \mu \mathrm{g} / \mathrm{mL} 4^{\prime}$, 6-diamidino-2-phenylindole (DAPI), and $30 \mu \mathrm{g} / \mathrm{mL}$ MitoTracker Green FM (MTG; Sharp and Pogliano 1999). After the completion of the membrane fusion event that is the final step of engulfment, the membrane-impermeable stain FM 4-64 is excluded from the forespore membrane and DAPI is excluded from the forespore nucleoid. When visualizing GFP, live cells were stained with a final concentration of $0.1 \mu \mathrm{g} / \mathrm{mL}$ MitoTracker Red and $0.2 \mu \mathrm{g} / \mathrm{mL}$ DAPI (Sharp and Pogliano 2002). All fluorescent stains were obtained from Molecular Probes. An Applied Precision optical sectioning microscope and Delta Vision software were used to collect and deconvolve the images, as has been previously described (Pogliano et al. 1999). Following deconvolution, images from the medial focal plane were saved as TIF files and imported into Adobe Photoshop.

\section{Overexpression and purification of His-SpoIID} and His-SpoIIP

His-tagged SpoIID was constructed by cloning the PvuII-toEcoRI fragment of SpoIID from p16-2 (a gift of A. Decatur and R. Losick) into pRSETc, fusing the entire coding region of spoIID to the poly-His linker. The resulting plasmid (pKP4) was transformed into E. coli strain BL21. His-tagged SpoIIP was constructed by the PCR amplification of the entire spoIIP coding sequence using the primers 5'-GGGAATTCAGATGGAAAAC CATTA-3' and 5'-AAAAGCTTCTTATTGTTTTTTCGTC-3' (restriction sites are underlined). The resulting PCR product was digested with EcoR1 and HindIII, and cloned into pRSETa. The resulting plasmid (pE14) was sequenced to ensure that no mutations had been introduced during cloning, and transformed into $E$. coli strain BL21. Two-hundred-fifty-milliliter cultures of BL21 (pKP4) and BL21 (pE14) were inoculated into LB medium containing $100 \mu \mathrm{g} / \mathrm{mL}$ ampicillin, and grown at $37^{\circ} \mathrm{C}$ to an $\mathrm{OD}_{600}$ of 0.5 and induced with $1 \mathrm{mM}$ isopropyl $\beta$-D-1-thiogalactopyranoside (IPTG). Three hours after induction, cells were harvested by centrifugation ( $8000 \mathrm{rpm}, 15 \mathrm{~min})$, and the pellet frozen at $-70^{\circ} \mathrm{C}$. The pellet was resuspended in Buffer A $16 \mathrm{M}$ GuHCl, $100 \mathrm{mM} \mathrm{NaPO}_{4}, 10 \mathrm{mM}$ TrisCl at $\mathrm{pH} 8.0$ ) at $5 \mathrm{~mL} / \mathrm{g}$ wet weight. The resuspension was stirred for $1 \mathrm{~h}$ at room temperature (RT), sonicated, and the lysate centrifuged at 10,000 $\mathrm{g}$ for $15 \mathrm{~min}$ at $4^{\circ} \mathrm{C}$. The supernatant was added to $8 \mathrm{~mL}$ of a $50 \%$ slurry of Ni-NTA resin (Qiagen) that was equilibrated in Buffer A. This mixture was rocked for $45 \mathrm{~min}$ at room temperature and then loaded onto a column (Bio-Rad). The column was washed with 10 column volumes of Buffer A, 5 column volumes of Buffer B (8 M urea, $100 \mathrm{mM} \mathrm{NaPO}, 10 \mathrm{mM}$ TrisCl at $\mathrm{pH} 8.0$ ), and 10 column volumes of Buffer C ( $8 \mathrm{M}$ urea, $100 \mathrm{mM} \mathrm{NaPO}_{4}$, $10 \mathrm{mM}$ TrisCl at $\mathrm{pH}$ 6.3) containing $50 \mathrm{mM}$ imidazole. HisSpoIID and His-SpoIIP were eluted off the columns with Buffer C containing $250 \mathrm{mM}$ imidazole. Eight $1.5-\mathrm{mL}$ fractions were collected.

\section{Purification of B. subtilis cell walls}

One liter of PY79 was grown at $37^{\circ} \mathrm{C}$ in liquid sporulation medium (DSM). Two hours after the initiation of sporulation, cells were harvested by centrifugation $\left(7000 \mathrm{~g}, 15 \mathrm{~min}, 4^{\circ} \mathrm{C}\right)$. The pellet was washed with $25 \mathrm{mM}$ TrisCl at $\mathrm{pH} 8.0$ for $30 \mathrm{~min}$ at $4^{\circ} \mathrm{C}$. After spinning the cells at $7000 \mathrm{~g}$ for $15 \mathrm{~min}$ at $4^{\circ} \mathrm{C}$ in microcentrifuge tubes, pellets were flash-frozen in liquid nitrogen and dried overnight in a speed-vac. One gram of the freeze-dried cells was resuspended in $80 \mathrm{~mL}$ of $4 \%(\mathrm{w} / \mathrm{v})$ SDS. The suspension was shaken for $90 \mathrm{~min}$ at $150 \mathrm{rpm}$ on a rotary shaker (RT) and sonicated for $5 \mathrm{~min}$ at $4^{\circ} \mathrm{C}$ (using ten 30 -sec cycles of sonication followed by cooling on ice). After sonication, the suspension was incubated at $100^{\circ} \mathrm{C}$ for $15 \mathrm{~min}$ and centrifuged $(12,000 \mathrm{~g}, 15 \mathrm{~min}, \mathrm{RT})$. To remove the SDS and membranes, the pellet was resuspended in $80 \mathrm{~mL}$ of $0.1 \%(\mathrm{v} / \mathrm{v})$ purified Triton $\mathrm{X}-100$ and incubated for $30 \mathrm{~min}$ at RT with gentle shaking. The suspension was centrifuged and the pellet was washed $4 \times$ for 30 min in $13 \mathrm{~mL}$ of deionized water $\left(\mathrm{diH}_{2} \mathrm{O}\right)$. The final pellet was freeze-dried overnight and resuspended as a $2 \%(\mathrm{w} / \mathrm{v})$ cell wall suspension in $\mathrm{diH}_{2} \mathrm{O}$ containing $0.02 \%(\mathrm{w} / \mathrm{v})$ sodium azide. The suspension was stored at $4^{\circ} \mathrm{C}$.

\section{Renaturing gel electrophoresis for cell wall hydrolytic activity}

Purified His-SpoIID and His-SpoIIP was subjected to SDSPAGE, with gels containing $0.1 \%(\mathrm{w} / \mathrm{v}) \mathrm{M}$. luteus cells (Sigma) or $0.1 \%(\mathrm{w} / \mathrm{v})$ purified B. subtilis cell wall as a substrate (Foster 1992). SDS-PAGE gels were run at $15 \mathrm{~mA}$ at room temperature. Following electrophoresis, gels were rinsed in deionized water, transferred to $300 \mathrm{~mL}$ of Renaturation solution $[25 \mathrm{mM}$ TrisCl at $\mathrm{pH} 7.2,1 \%(\mathrm{v} / \mathrm{v})$ Triton X-100], and incubated at $37^{\circ} \mathrm{C}$ for 16 $\mathrm{h}$ with gentle shaking. Gels were rinsed with deionized water, stained with $0.01 \%(\mathrm{w} / \mathrm{v})$ methylene blue in $0.01 \%(\mathrm{w} / \mathrm{v}) \mathrm{KOH}$ for $3 \mathrm{~h}$, and destained with deionized water. Zones of clearing in the blue background indicated cell wall hydrolytic activity. Lysozyme and bovine serum albumin (BSA) were used as positive and negative controls, respectively, because we noted that overloaded proteins show a small amount of clearing in these assays, even when the protein completely lacks hydrolase activity. This small amount of clearing can be seen for BSA in Figure 5. However, such clearing is always partial and appears only after destaining, indicating that peptidoglycan remains in the region of the band and suggesting that the high concentration of protein somehow reduces the affinity of methylene blue for peptidoglycan. In contrast, peptidoglycan hydrolases such as SpoIID and lysozyme mediate the rapid and complete clearing of peptidoglycan even in the absence of overloading (such as Fig. 5, lanes 1,2, for SpoIID), and this clearing is apparent before destaining.

\section{Electron microscopy}

Electron microscopy was performed as described in Perez et al. (2000) using method IV.

\section{Acknowledgments}

We thank Joe Pogliano and Marc Sharp for performing the mutagenesis and primary screen from which spoIIP95-2 was isolated, and Patrick Stragier and Richard Losick for providing strains. We would also like to thank Karen D. Xu for construction of the genomic library and assistance with the genetic screen, Nathalia Cota for characterization of the spoIIS mutant, Charlotte Frank for assistance with construction of the GFP fusions, and Kiyoteru Tokuyasu and C. Lance Washington for their helpful advice and technical assistance with electron microscopy. DNA sequencing was partially funded by the NCI 
Cancer Center Support Grant no. 2 P30 CA23100-18. This work was supported by the National Institutes of Health (GM57045 and GM57045-S1).

The publication costs of this article were defrayed in part by payment of page charges. This article must therefore be hereby marked "advertisement" in accordance with 18 USC section 1734 solely to indicate this fact.

\section{References}

Adler, E., Barak, I., and Stragier, P. 2001. Bacillus subtilis locus encoding a killer protein and its antidote. J. Bacteriol. 183: 3574-3581.

Barrett, J.F., Dolinger, D.L., Schramm, V.L., and Shockman, G.D. 1984. The mechanism of soluble peptidoglycan hydrolysis by an autolytic muramidase. A processive exodisaccharidase. J. Biol. Chem. 259: 11818-11827.

Blackman, S.A., Smith, T.J., and Foster, S.J. 1998. The role of autolysins during vegetative growth of Bacillus subtilis 168 . Microbiology 144: 73-82.

Driks, A., Roels, S., Beall, B., Moran Jr., C.P., and Losick, R. 1994. Subcellular localization of proteins involved in the assembly of the spore coat of Bacillus subtilis. Genes \& Dev. 8: 234-244.

Dubnau, D. and Davidoff-Abelson, R. 1971. Fate of transforming DNA following uptake by competent Bacillus subtilis. I. Mol. Biol. 56: 209-221.

Eichenberger, P., Fawcett, P., and Losick, R. 2001. A three-protein inhibitor of polar septation during sporulation in Bacillus subtilis. Mol. Microbiol. 42: 1147-1162.

Feilmeier, B.J., Iseminger, G., Schroeder, D., Webber, H., and Phillips, G.J. 2000. Green fluorescent protein functions as a reporter for protein localization in Escherichia coli. J. Bacteriol. 182: 4068-4076.

Fitz-James, P.C. 1964. Sporulation in spheroplasts and its dependence on prior forespore development. J. Bacteriol. 87: 667-675.

Foster, S.J. 1992. Analysis of the autolysins of Bacillus subtilis 168 during vegetative growth and differentiation by using renaturing polyacrylamide gel electrophoresis. J. Bacteriol. 174: 464-470.

Foster, S.J. and Popham, D.L. 2002. Structure and synthesis of cell wall, spore cortex, teichoic acids, S-layers, and capsules. In Bacillus subtilis and its relatives: From genes to cells (eds. A.L. Sonenshein, J.A. Hoch, and R. Losick), pp. 21-42. American Society for Microbiology, Washington, D.C.

Frandsen, N. and Stragier, P. 1995. Identification and characterization of the Bacillus subtilis spoIIP locus. I. Bacteriol. 177: 716-722.

Gordon, G.S. and Wright, A. 2000. DNA segregation in bacteria. Annu. Rev. Microbiol. 54: 681-708.

Guerout-Fleury, A.M., Frandsen, N., and Stragier, P. 1996. Plasmids for ectopic integration in Bacillus subtilis. Gene 180: $57-61$.

Herbold, D.R. and Glaser, L. 1975. Interaction of $N$-acetylmuramic acid L-alanine amidase with cell wall polymers. $J$. Biol. Chem. 250: 7231-7238.

Hiraga, S. 2000. Dynamic localization of bacterial and plasmid chromosomes. Annu. Rev. Genet. 34: 21-59.

Holtje, J.V. 1996. Lytic transglycosylases. EXS 75: 425-429.

- 1998. Growth of the stress-bearing and shape-maintaining murein sacculus of Escherichia coli. Microbiol. Mol. Biol. Rev. 62: 181-203.

Jensen, R.B. and Shapiro, L. 2000. Proteins on the move: Dynamic protein localization in prokaryotes. Trends Cell Biol.
10: $483-488$

Kuroda, A., Rashid, M.H., and Sekiguchi, J. 1992. Molecular cloning and sequencing of the upstream region of the major Bacillus subtilis autolysis gene: A modifier protein exhibiting sequence homology to the major autolysin and the spoIID product. J. Gen. Microbiol. 138: 1064-1076.

Lemon, K.P. and Grossman, A.D. 2001. The extrusion-capture model for chromosome partitioning in bacteria. Genes \& Dev. 15: 2031-2041.

Londoño-Vallejo, J.-A., Fréhel, C., and Stragier, P. 1997. spoIIQ, a forespore-expressed gene required for engulfment in Bacillus subtilis. Mol. Microbiol. 24: 29-39.

Lopez-Diaz, I., Clarke, S., and Mandelstam, J. 1986. spoIID operon of Bacillus subtilis: cloning and sequence. J. Gen. Microbiol. 132: 341-354.

Lopilato, J., Bortner, S., and Beckwith, J. 1986. Mutations in a new chromosomal gene of Escherichia coli K-12, $p c n B$, reduce plasmid copy number of pBR322 and its derivatives. Mol. Gen. Genet. 205: 285-290.

Ma, J., Campbell, A., and Karlin, S. 2002. Correlations between Shine-Dalgarno sequences and gene features such as predicted expression levels and operon structures. J. Bacteriol. 184: 5733-5745.

Margolis, P.S., Driks, A., and Losick, R. 1993. Sporulation gene spoIIB from Bacillus subtilis. J. Bacteriol. 175: 528-540.

Perez, A.R., Abanes-De Mello, A., and Pogliano, K. 2000. SpoIIB localizes to active sites of septal biogenesis and spatially regulates septal thinning during engulfment in Bacillus subtilis. J. Bacteriol. 182: 1096-1108.

Piggot, P.J. and Losick, R. 2002. Sporulation genes and intercompartmental regulation. In Bacillus subtilis and its relatives: From genes to cells (eds. A.L. Sonenshein, J.A. Hoch, and R. Losick), pp. 483-518. American Society for Microbiology, Washington, D.C.

Piggot, P.J., Bylund, J.E., and Higgins, M.L. 1994. Morphogenesis and gene expression during sporulation. In Regulation of bacterial differentiation (eds. P. Piggot, C.P. Moran, and P. Youngman), pp. 113-137. American Society for Microbiology, Washington, D.C

Pogliano, J., Osborne, N., Sharp, M., Abanes-De Mello, A., Perez, A.R., Sun, Y.-L., and Pogliano, K. 1999. A vital stain for studying membrane dynamics in bacteria: A novel mechanism controlling septation during Bacillus subtilis sporulation. Mol. Microbiol. 31: 1149-1159.

Rocha, E.P., Danchin, A., and Viari, A. 1999. Translation in Bacillus subtilis: Roles and trends of initiation and termination, insights from a genome analysis. Nucleic Acids Res. 27: 3567-3576.

Sandman, K., Losick, R., and Youngman, P. 1987. Genetic analysis of Bacillus subtilis spo mutations generated by Tn917-mediated insertional mutagenesis. Genetics 117: 603-617.

Schaeffer, P., Millet, J., and Aubert, J. 1965. Catabolite repression of bacterial sporulation. Proc. Natl. Acad. Sci. 54: 704711

Shapiro, L. and Losick, R. 1997. Protein localization and cell fate in bacteria. Science 276: 712-718

Sharp, M.D. and Pogliano, K. 1999. An in vivo membrane fusion assay implicates SpoIIIE in the final stages of engulfment during Bacillus subtilis sporulation. Proc. Natl. Acad. Sci. 96: $14553-14558$.

. 2002. Role of cell specific assembly of SpoIIIE in polarity of DNA transfer. Science 295: 137-139.

Shine, J. and Dalgarno, L. 1974. The 3' terminal sequence of Escherichia coli 16S ribosomal RNA: Complementarity to nonsense triplets and ribosome binding sites. Proc. Natl. 


\section{Abanes-De Mello et al.}

Acad. Sci. 71: 1342-1346.

Smith, K., Bayer, M.E., and Youngman, P. 1993. Physical and functional characterization of the Bacillus subtilis spoIIM gene. J. Bacteriol. 175: 3607-3617.

Sterlini, J.M. and Mandelstam, J. 1969. Commitment to sporulation in Bacillus subtilis and its relationship to development of actinomycin resistance. Biochem. J. 113: 29-37.

Stragier, P. 2002. A gene odyssey: Exploring the genomes of endospore-forming bacteria. In Bacillus subtilis and its relatives: From genes to cells (eds. A.L. Sonenshein, J.A. Hoch, and R. Losick), pp. 519-526. American Society for Microbiology, Washington, D.C.

Stragier, P. and Losick, R. 1996. Molecular genetics of sporulation in Bacillus subtilis. Annu. Rev. Genet. 30: 297-341.

Sun, Y.-L., Sharp, M.D., and Pogliano, K. 2000. A dispensable role for forespore-specific gene expression in engulfment of the forespore during sporulation of Bacillus subtilis. J. Bacteriol. 182: 2919-2927.

Youngman, P., Perkins, J.B., and Sandman, K. 1984. New genetic methods, molecular cloning strategies, and gene fusion techniques for Bacillus subtilis which take advantage of Tn917 insertional mutagenesis. In Genetics and biotechnology of bacilli (eds. J.A. Hoch and A.T. Ganesan), pp. 103-111. Academic Press, New York.

Zhou, Y., Zhang, X., and Ebright, R.H. 1991. Random mutagenesis of gene-sized DNA molecules by use of PCR with Taq DNA polymerase. Nucleic Acids Res. 19: 6052. 


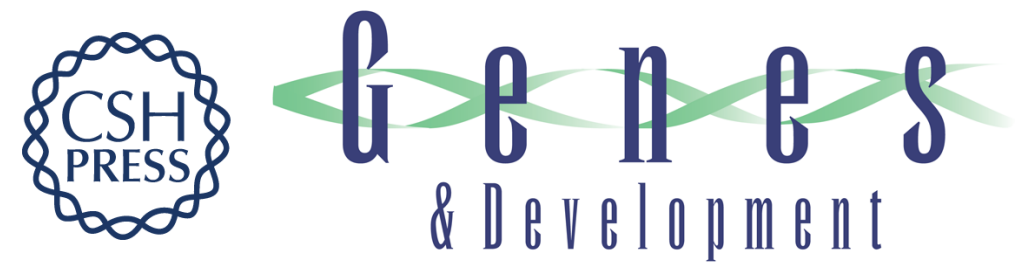

\section{A cytoskeleton-like role for the bacterial cell wall during engulfment of the Bacillus subtilis forespore}

Angelica Abanes-De Mello, Ya-Lin Sun, Stefan Aung, et al.

Genes Dev. 2002, 16:

Access the most recent version at doi:10.1101/gad.1039902

Supplemental
Material http://genesdev.cshlp.org/content/suppl/2002/12/22/16.24.3253.DC1

References This article cites 38 articles, 22 of which can be accessed free at:

http://genesdev.cshlp.org/content/16/24/3253.full.html\#ref-list-1

License

Email Alerting

Receive free email alerts when new articles cite this article - sign up in the box at the top

Service

right corner of the article or click here.

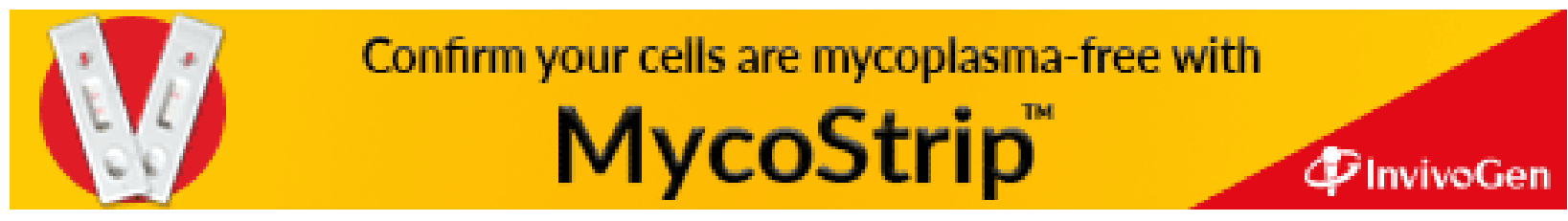

